\title{
Feral pig hunting: a risk factor for human brucellosis in north-west NSW?
}

\section{Melissa J. Irwin ${ }^{\mathrm{A}, \mathrm{B}, \mathrm{C}, \mathrm{F}}$, Peter D. Massey, Belinda Walker' and David N. Durrheim ${ }^{\mathrm{B}, \mathrm{E}}$}

ASouth Eastern Sydney Illawarra Area Health Service

${ }^{\mathrm{B} H u n t e r ~ N e w ~ E n g l a n d ~ A r e a ~ H e a l t h ~ S e r v i c e ~}$

${ }^{\mathrm{C}} N \mathrm{SW}$ Public Health Officer Training Program

DNSW Department of Industry and Investment

${ }^{\mathrm{E}}$ Hunter Medical Research Institute

FCorresponding author. Email: melissa.irwin@

sesiahs.health.nsw.gov.au following the National Brucellosis and Tuberculosis Eradication Campaign. ${ }^{6}$

Although rare in Australia, brucellosis is the most common zoonosis worldwide and is an illness that can be acquired through travel. ${ }^{7,8}$ Unfortunately, serological tests by which most human diagnoses are made cannot distinguish between Brucella species and therefore it is difficult to determine the relative contribution of locally acquired B. suis and overseas acquired species.

This article reports the findings of the human and animal health investigation that followed the notification of four human brucellosis cases and which aimed to identify B. suis in feral pigs in rural north-west NSW.

\section{Public health investigation and findings}

Between December 2006 and September 2009, four men who met the clinical and laboratory case definition for brucellosis were notified to Hunter New England Population Health. All described regular recreational or occupational feral pig hunting prior to the onset of their symptoms. They reported hunting close to Moree, which is located approximately $120 \mathrm{~km}$ from the Queensland border, with one also hunting around the Queensland border. All described butchering carcasses without using personal protective equipment. None of their hunting companions reported similar illness and none reported overseas travel or consumption of unpasteurised dairy products from countries in which Brucella is endemic in the 3 months prior to the onset of their illness.

All cases were diagnosed by serology which was conducted using the standard agglutination test (SAT). Only one case had blood cultured, more than 5 months after the onset of his illness, and Brucella was not detected. Therefore, the Brucella species causing the case's illness was not confirmed. All cases were symptomatic at presentation and their symptoms included fever, sweats, abdominal pain, vomiting and loin and back pain. They were treated with doxycycline and rifampicin for the recommended period and recovered. Table 1 summarises the demographic, clinical, laboratory and hunting location details of the four cases.

\section{Animal health investigation and findings}

Blood sampling of trapped feral pigs in the region where human cases had occurred was arranged through the 
Table 1. Characteristics of four men from NSW diagnosed with brucellosis between 2006 and 2009

\begin{tabular}{|c|c|c|c|c|c|c|}
\hline Case no. & $\begin{array}{c}\text { Age } \\
\text { (years) }\end{array}$ & $\begin{array}{c}\text { Year of } \\
\text { diagnosis }\end{array}$ & $\begin{array}{l}\text { SAT titre on } \\
\text { diagnosis }^{A}\end{array}$ & Blood culture & $\begin{array}{l}\text { Time from symptom } \\
\text { onset to diagnosis } \\
\text { (weeks) }\end{array}$ & Hunting area \\
\hline 1 & 64 & 2009 & 1280 & Not performed & 7 & Moree area \\
\hline 2 & 29 & 2008 & 320 & Not performed & 3 & Moree to Queensland border \\
\hline 3 & 41 & 2008 & 320 & Brucella not detected & 26 & Moree area \\
\hline 4 & 31 & 2006 & 1280 & Not performed & 5 & Moree area \\
\hline
\end{tabular}

NSW Department of Industry and Investment (I \& I NSW) with the cooperation of the North West Livestock Health and Pest Authority. Samples from over 200 pigs on 31 separate trapping occasions from different locations were submitted for serology. None of these samples were positive for Brucella serology, whereas 20 were positive for Leptospira, 17 for Leptospira interrogans serovar pomona and three for Leptospira borgpetersenii serovar tarassovi; both these serovars are pathogenic to humans.

In a separate investigation, Australian Quarantine Inspection Service (AQIS) officers arranged for the culture of testicular abscesses that had resulted in feral pig carcasses bound for export being condemned. Testicular abscesses in the absence of injury are a good indicator of brucellosis in feral pigs. While several testicular samples sourced from feral pigs from southern Queensland identified $B$. suis, those sourced from northern NSW did not. However, it is not unusual for old abscesses caused by brucellosis to have no viable bacteria.

\section{Discussion}

Human brucellosis and leptospirosis are notifiable by pathology laboratories under the NSW Public Health Act 1991. Human brucellosis surveillance needs to differentiate local from overseas acquired cases, as local acquisition has implications for Australia's animal health. ${ }^{9}$ If locally acquired B. abortus or B. melitensis were detected, this would affect Australia's brucellosis-free status. If locally acquired B. suis is identified, I \& I NSW should be notified so that the source, presumably feral pigs, can be investigated and targeted for eradication, reducing the risk to humans.

Animal surveillance for B. abortus is ongoing and is reported in Animal Health Australia's National Animal Health Information System. Despite extensive testing, B. abortus has not been detected in recent years. ${ }^{10}$

While $B$. suis was not identified in the four men or the feral pigs tested in NSW, pigs are able to cross the border from
Queensland where the disease is known to occur and could have been the source of infection. The presence of potentially zoonotic Leptospira infection in feral pigs from north-west NSW was confirmed by this investigation. Therefore, this collaboration between human and animal health agencies allowed for an improved understanding of the epizoology of local feral pigs and the potential risk to humans, and identified a novel surveillance mechanism (sampling condemned export carcasses) for monitoring the health of feral pigs in a defined catchment area.

\section{Conclusion}

Although human brucellosis and leptospirosis are rare, feral pig hunting is likely to be a risk factor for locally acquired disease in north-west NSW. We propose that the surveillance of human brucellosis be strengthened by: investigating and reporting for cases, the likely place of disease acquisition (Australian state/s or overseas) and participation in feral pig hunting activities (for locally acquired cases); and by encouraging speciation of Brucella through blood culture. In addition, an ongoing collaboration with animal health colleagues is required to confirm $B$. suis infection in NSW feral pigs and subsequent transmission to feral pig hunters.

\section{Acknowledgments}

This work was conducted during a rural placement of the NSW Public Health Officer Training Program. The authors would like to thank Bill Hetherington and the veterinarians and rangers of the North West Livestock Health and Pest Authority for conducting the trapping and sampling of feral pigs; David Cox from the Australian Quarantine Inspection Service for arranging culture of testicular abscesses from feral pig carcasses; the Elizabeth Macarthur Agricultural Institute for performing the animal pathology testing; and David Dickeson from the Centre for Infectious Diseases and Microbiological Laboratory Services, ICPMR, for his advice on the serology of brucellosis and leptospirosis.

\section{References}

1. Robson JM, Harrison MW, Wood RN, Tilse MH, McKay AB, Brodribb TR. Brucellosis: re-emergence and changing epidemiology in Queensland. Med J Aust 1993; 159(3): $153-8$. 
2. Centers for Disease Control and Prevention (CDC). Brucella suis infection associated with feral swine hunting - three states, 2007-2008. MMWR Morb Mortal Wkly Rep 2009; 58(22): 618-21.

3. Vicente J, Leon-Vizcaino L, Gortazar C, Jose Cubero M, Gonzalez M, Martin-Atance P. Antibodies to selected viral and bacterial pathogens in European wild boars from southcentral Spain. J Wildl Dis 2002; 38(3): 649-52.

4. Hone (1990a) cited in Choquenot D, Mcllroy J and Korn T. Managing Vertebrate Pests: Feral Pigs. Canberra: Australian Government Publishing Service; 1996.

5. Tinsdell (1982) cited in Choquenot D, McIllroy J and Korn T. Managing Vertebrate Pests: Feral Pigs. Canberra: Australian Government Publishing Service; 1996.

6. Gilbert GL. Brucellosis: continuing risk. Med J Aust 1993; 159(3): 147-8.
7. Pappas G, Papadimitriou P, Akritidis N, Christou L, Tsianos EV. The new global map of human brucellosis. Lancet Infect Dis 2006; 6(2): 91-9. doi:10.1016/S1473-3099(06)70382-6

8. Memish Z, Balkhy H. Brucellosis and international travel. J Travel Med 2004; 11(1): 49-55.

9. NSW Health. Brucellosis: Response Protocol for NSW Public Health Units. Notifiable Diseases Manual. North Sydney: NSW Health; September 2004. Available from: http://www. health.nsw.gov.au/factsheets/guideline/brucellosis.html (Cited 7 September 2009.)

10. Animal Health Australia. National Animal Health Information System. Brucellosis testing: Results of tests for bovine brucellosis in cattle (by Australian state or territory). Available from: http://www.animalhealthaustralia.com.au/ nahis/public.php?page $=$ out_showtable\&outputid $=29$ (Cited 10 September 2009.) 